\title{
A proteomic profile of postpartum cervical repair in mice
}

\author{
Robert Lee Stanley, Takako Ohashi, Jacob Gordon and Chishimba Nathan Mowa
}

Department of Biology, Appalachian State University, Boone, North Carolina, USA

Correspondence should be addressed to C Nathan Mowa: mowacn@appstate.edu

\begin{abstract}
A timely and complete uterine cervical tissue repair postpartum is of necessity to prevent obstetrical complications, such as cervicitis, ectropion, hemorrhage, repeated miscarriages or abortions and possibly preterm labor and malignancies. We recently characterized the morphological alterations, as well as changes in angiogenic expression profile in a mice uterine cervix during the immediate postpartum period. Here, we build on this previous study using a proteomic analysis to profile postpartum tissue changes in mice cervix during the same period, the first $48 \mathrm{~h}$ of postpartum. The current proteomics data reveal a variable expression of several intermediate filaments, cytoskeletal modulators and proteins with immune and/or wound-healing properties. We conclude that postpartum cervical repair involves a rapid and tightly regulated balance between a host of biological factors, notably between anti- and pro-inflammatory factors, executed by the M1 and M2 macrophage cells, as revealed by proteomics and verified by confocal immunofluorescence. Future studies will assess the suitability of some of the key proteins identified in this study as potential markers for determining the phase of postpartum cervical repair in obstetrical complications, such as cervical lacerations.
\end{abstract}

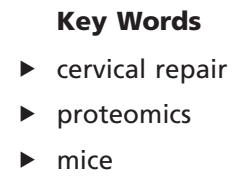

Journal of Molecular Endocrinology

(2018) 60, 17-28

\section{Introduction}

Since the uterine cervix undergoes marked alterations during pregnancy and significant trauma both during normal vaginal delivery (parturition) and immediately after (postpartum) (Timmons et al. 2010), a timely and complete tissue repair, postpartum, is of necessity to prevent obstetrical complications. Such (obstetrical) complications include cervicitis, ectropion, hemorrhage, repeated miscarriages or abortions and, possibly, preterm labor and malignancies. Collectively, these physiological, biochemical and biophysical changes are termed cervical remodeling (CR), which is divided into four distinct yet overlapping phases, namely softening, ripening, dilation and postpartum repair (Read et al. 2007, Word et al. 2007). To date, most of the studies have focused on the first three phases of CR, almost at the exclusion of postpartum repair.

\begin{tabular}{|lr}
\hline http://jme.endocrinology-journals.org & ○ 2018 Society for Endocrinology \\
https://doi.org/10.1530/JME-17-0179 & Published by Bioscientifica Ltd. \\
Printed in Great Britain
\end{tabular}

Postpartum repair (sometimes termed reconstruction) consists of a set of complex biological processes that ultimately restores the cervix to its original non-pregnant state, and thus ensures a normal cervical function for subsequent pregnancies (Timmons et al. 2010, Mahendroo 2012, Stanley et al. 2015). This final phase of $\mathrm{CR}$ is generally characterized as an inflammatory and wound-healing response (Timmons \& Mahendroo 2007, Bauer et al. 2009), as demonstrated by studies that utilized gene microarrays. These studies have shown that a variety of factors, including pro-inflammatory factors, metalloproteases, proteins involved in extracellular matrix (ECM) synthesis and genes governing epithelial differentiation pathways, are all upregulated postpartum (Timmons \& Mahendroo 2007, Gonzalez et al. 2009). 
Immune cells, including neutrophils, eosinophils and both M1 and M2 macrophages, have all been shown to increase in expression postpartum compared to earlier phases of remodeling (Timmons et al. 2009, 2010, Mahendroo 2012). We have also recently shown marked and varied changes in the expression of angiogenic factors (Stanley et al. 2015). These marked angiogenic and inflammatory responses could serve to promote repair of the cervix after parturition and/or serve a protective role of the birth canal against environmental hazards, such as infection (Gonzalez et al. 2009).

Given the facts that postpartum repair is characterized as a pro-inflammatory wound-healing response (Timmons \& Mahendroo 2007, Bauer et al. 2009, Mahendroo 2012, Stanley et al. 2015), in the present study, we sought to identify the signature proteins and their potential roles during the first $48 \mathrm{~h}$ of postpartum using the proteomics analysis.

\section{Materials and methods}

\section{Animals and postpartum time intervals}

Pregnant wild-type mice (C57BL6/129SvEv; Charles River, $n=3$ ) were used for all the groups in the present study. The time of the first pup was noted as time $0 \mathrm{~h}$ and the mothers were killed at time 0,15 and $48 \mathrm{~h}$ after parturition. The forty-eight (48) hour postpartum time point was used as the baseline here, based on findings from our previous studies which showed that the expression of molecules in the rodent cervix restores back to non-pregnancy to early pregnancy levels by $48 \mathrm{~h}$ or day 2 postpartum (Mowa et al. 2004). All animals were euthanized by a lethal injection of sodium pentobarbital $(150 \mathrm{mg} / \mathrm{kg}$ body weight, i.p.) and transcardially perfused with $0.9 \%$ saline solution. Cervices were carefully harvested under a stereomicroscope to avoid contamination with vaginal and uterine tissues, and the tissues were then processed and analyzed accordingly. All animals were housed under the following conditions: constant room temperature; a 12:12 light and dark cycle, and free access to water and food. All experiments were performed in accordance with the Institutional Animal Care and Use Committee (IACUC) of Appalachian State University and the NIH guidelines (NIH publication number 86-23), with efforts made to minimize both number of animals used and animal suffering.

\section{Proteomics}

Whole protein was extracted from cervical tissue at 0,15 and $48 \mathrm{~h}$ postpartum ( $n=3$ per time point), as described below.
The supernatant was then immediately stored at $-80^{\circ} \mathrm{C}$ and later transported to the core facility Laboratory of the David Murdock Research Institute (Kannapolis, North Carolina, USA) under dry ice for the proteomics analysis.

Sample preparation: The samples were assayed using the Thermo Scientific Micro BCA Protein Assay kit to determine protein concentration. The samples were diluted to fall within the linear working range of the kit $(5-200 \mu \mathrm{g} / \mathrm{mL})$ and the concentrations were calculated based on absorbance values compared to a BSA standard curve. The samples were then filtered using a 3-kDa ultracentrifugal filter to exchange the dissolution solvent with a mass spectrometry-friendly buffer. $100 \mu \mathrm{L}$ of the sample was diluted to $500 \mu \mathrm{L}$ with $50 \mathrm{mM}$ ammonium bicarbonate and filtered. The samples were rinsed with $200 \mu \mathrm{L}$ ammonium bicarbonate and filtered. The tubes were inverted and centrifuged to collect the sample.

A volume of each sample corresponding to $35 \mu \mathrm{g}$ of protein (based on the protein quantization results) was used. The sample volumes were made equal by adding $50 \mathrm{mM}$ ammonium bicarbonate (AmBic) to a volume of $29.8 \mu \mathrm{L}$. A $1 \%$ solution of Rapigest was added to each sample to denature the proteins and the mixture was placed in a shaking heated mixer at $40^{\circ} \mathrm{C}$ for $10 \mathrm{~min}$. Disulfide bonds were reduced by adding $200 \mathrm{mM}$ dithiothreitol to each sample and heating the tubes to $80^{\circ} \mathrm{C}$ for $15 \mathrm{~min}$. Free sulfur atoms were alkylated with $400 \mathrm{mM}$ Iodoacetamide by placing the tubes in the dark for $30 \mathrm{~min}$ at room temperature. A tryptic digest was performed by adding $0.7 \mu \mathrm{g}$ Gold-Mass Spectrometry grade trypsin to each tube and incubating overnight at $37^{\circ} \mathrm{C}$. Alcohol dehydrogenase (ADH) digest from yeast was added to a final concentration of $50 \mathrm{fmol} / \mu \mathrm{g}$ protein. The trypsin reaction was stopped and the Rapigest was degraded with the addition of $10 \%$ TFA $/ 20 \%$ acetonitrile/70\% water that was then heated to $60^{\circ} \mathrm{C}$ for $2 \mathrm{~h}$. The samples were centrifuged and the supernatant pipetted into autosampler vials.

A protein standard (BSA) was carried through the reduction/alkylation and digestion steps and used as a QC of the sample preparation steps and instrument performance. LC solvents for peptide separation included (a) water containing $0.1 \%$ formic acid, and (b) acetonitrile containing $0.1 \%$ formic acid. The study sequence consisted of the study sample injections bracketed by a pair of QC injections. Data from all study samples were acquired using Data Dependent scans (Nth order double play) on the LTQ Orbitrap XL. Database searches were performed in Elucidator (Rosetta Biosoftware) using MASCOT (Matrix Sciences, London, UK). Analytical results were also viewed in Scaffold (Proteome Software, 
Portland, OR, USA). QC and study samples were evaluated to confirm data quality. Liquid chromatography total ion current (TIC) outputs were assessed for signal quality and changes in signal intensity. Results were also monitored for signal trends, such as a consistent increase or decrease in TIC maximum values, and MASCOT search results were used to monitor the quality of the MS data.

\section{Proteomics verification}

The proteomics data were verified by confocal immunofluorescence of two proteins and the procedure was performed as described below:

Confocal immunofluorescence was employed to complement Western blot data of the proteins of interest (filamin-A and vimentin). Harvested cervices ( 0 and $48 \mathrm{~h}$ postpartum) were immersed in a $10 \%$ formalin ( $\mathrm{pH} 7.2$ ) aqueous solution. The tissues were fixed in formalin at $4^{\circ} \mathrm{C}$ for 3-4 days and then transferred into saturated sucrose dissolved in $0.1 \mathrm{M}$ PBS, for at least 2 days prior to sectioning $(12 \mu \mathrm{m})$ with the cryostat (Leica) at $-30^{\circ} \mathrm{C}$. After sectioning, the slides were either stained immediately or stored at $-20^{\circ} \mathrm{C}$ until staining. For staining, the sections were initially incubated with $10 \%$ normal goat serum in 0.1 M PBS for $20 \mathrm{~min}$ at RT in order to block non-specific protein binding. Next, the sections were washed thrice in $0.1 \mathrm{M} \mathrm{PBS}$ and then incubated overnight at $4^{\circ} \mathrm{C}$ with diluted primary antibodies of interest at $0.5 \mu \mathrm{g} / \mathrm{mL}$ (sc-28284 (filamin-A, rabbit polyclonal IgG), sc-32322 (vimentin, mouse monoclonal); Santa Cruz Biotech). The next day, the sections were washed thrice with $0.1 \mathrm{M}$ PBS buffer followed immediately by incubation in diluted fluorotagged secondary antibody at $0.5 \mu \mathrm{g} / \mathrm{mL}$ (filamin-A, mouse anti-rabbit IgG-R (sc-2492); vimentin, goat anti-mouse IgG (sc-2781), Santa Cruz Biotech) for $1 \mathrm{~h}$ at RT. Thereafter, the sections were washed thrice with $0.1 \mathrm{M}$ PBS, counterstained with $5 \mu \mathrm{M}$ Sytox Green, mounted with aqueous Ultracruz Mounting Medium (Santa Cruz Biotech) and then examined with a confocal microscope (Carl Zeiss).

\section{Statistical analysis}

Raw MS data files for the study samples, collected by the Thermo Orbitrap XL system, were processed in Elucidator. MS data were grouped in Elucidator based on sample group and alignment (Table 1). Sample groups were used to assist

Table 1 LC and MS instrument parameters used in the study.

\begin{tabular}{|c|c|c|}
\hline System & Parameter & Setting \\
\hline \multirow[t]{2}{*}{ Autosampler } & Temperature & $4^{\circ} \mathrm{C}$ \\
\hline & Injection & $5.0 \mu \mathrm{L}$ prepared sample \\
\hline \multirow[t]{2}{*}{ LC Trap Column } & Sample load time & $5 \mathrm{~min}$ \\
\hline & Trap flow rate & $5 \mu \mathrm{L} / \min$ \\
\hline \multirow[t]{3}{*}{ LC Analytical Column } & Column temperature & $55^{\circ} \mathrm{C}$ \\
\hline & Flow rate & $0.4 \mu \mathrm{L} / \mathrm{min}$ \\
\hline & Gradient & $\begin{array}{l}\text { Initial conditions: } 98 \% \text { A } \\
t=60 \mathrm{~min}, 60 \% \mathrm{~A} \\
t=65 \mathrm{~min}, 5 \% \mathrm{~A} \\
t=70 \mathrm{~min}, 5 \% \mathrm{~A} \\
t=75 \mathrm{~min}, 98 \% \mathrm{~A} \\
t=95 \mathrm{~min}, 98 \% \mathrm{~A}\end{array}$ \\
\hline \multirow[t]{16}{*}{ LTQ Orbitrap XL mass spectrometer } & Experiment type & Nth order double play \\
\hline & \# Dependent scans & 5 \\
\hline & Source voltage & $2.0 \mathrm{kV}$ \\
\hline & Capillary temperature & $200^{\circ} \mathrm{C}$ \\
\hline & Source current & $1.0 \mu \mathrm{A}$ \\
\hline & Capillary voltage & $47.0 \mathrm{~V}$ \\
\hline & Tube lens & $100.0 \mathrm{~V}$ \\
\hline & FTMS survey scan time & $1.0 \mathrm{~s}$ \\
\hline & FTMS resolution & 60,000 \\
\hline & Survey time & $90 \mathrm{~min}$ \\
\hline & Survey ion mode & ES mode \\
\hline & Survey polarity & Positive \\
\hline & Survey mass range & $375-2000$ \\
\hline & Activation type & CID \\
\hline & Normalized collision energy & 35.0 \\
\hline & ITMS MS/MS mass range & $50-2000$ \\
\hline
\end{tabular}

Analytical samples were analyzed on a Thermo Scientific LTQ Orbitrap XL mass spectrometry system coupled to a Waters nano ACQUITY UPLC system using parameters presented in the table below. 
in data alignment and feature identification, and were utilized for QC assessment and group comparisons. Data were processed from retention time, 8-90 min. Thermo Orbitrap data files were searched using the Mascot search engine against the SwissProt mouse database (appended with yeast ADH, March 02, 2010). The aligned mass features were annotated with these database search results using the results from the system Peptide Tellers and a predicted error rate of $1 \%$. MS data were summarized to the feature level, normalized and an error-weighted ANOVA test was performed to compare the expression results between sample groups. Candidate differentially expressed markers were determined based on $P<0.01$. Features were summarized by protein based on the results of the database search.

\section{Results}

\section{Proteomics and confocal immunofluorescence analysis of postpartum cervical tissue}

Using the Rosetta Elucidator, several distinct proteins were identified in the cervical tissue of postpartum mice (Fig. 1). Proteomics analysis revealed several groups of proteins that were found to have significant changes in expression between $0 \mathrm{~h}$ and $48 \mathrm{~h}$ PP. These proteins were divided into four functional groups, namely: (1) four actin-binding proteins (gelsolin, filamin-A, D isoform of plectin-1 and transgelin) (Fig. 2), (2) four intermediate filaments (keratins types I 8 and II 18, desmin and vimentin) (Fig. 3), (3) six immune-related proteins (glutamine gamma-glutamyltranferase 2, gelsolin, lymphocyte antigen 6D, macrophage migration inhibitory factor (MIF), annexin A1 and phospholipase A2) (Fig. 4) and (4) two hypoxia-induced proteins (transgelin and vimentin) (Fig. 5). Levels of the majority of the functional groups of proteins (three out of four groups, namely actin-binding proteins, intermediate filaments and hypoxia-induced proteins) were most pronounced at $0 \mathrm{~h}$ but diminished by $48 \mathrm{~h}$ postpartum (Figs 2, 3 and 5 , Tables 2 and 3). The proteomics data were verified by confocal immunofluorescence analysis of filamin-A and vimentin (Figs 2 and 5, respectively). In contrast, the expression profiles of proteins involved in immune modulation and/or wound healing were variable, i.e., half of the six proteins (glutamine gamma-glutamyltransferase 2 , lyphocyte antigen $6 \mathrm{D}$ and gelsolin) were high at $0 \mathrm{~h}$ but decreased by $48 \mathrm{~h}$ PP, whereas the expressions of the other half (phospholipase A2, annexin A1 and macrophage MIF) were opposite of the first half (Fig. 4 and Table 2).

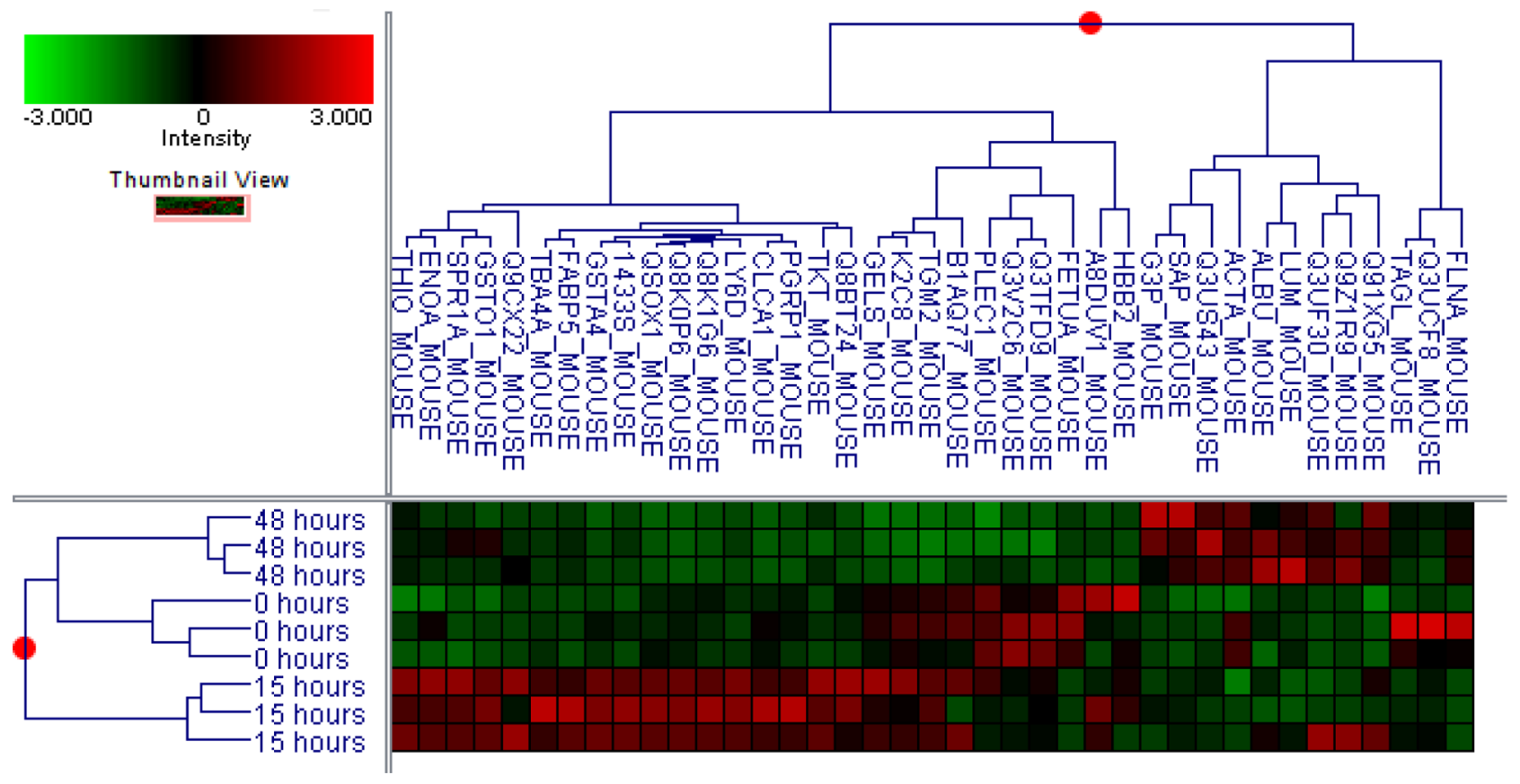

Figure 1

A distinct proteome-wide expression profile in cervix of postpartum mice in the first $48 \mathrm{~h}$. Cluster analysis reveals differentially expressed proteins of immediate postpartum ( $0 \mathrm{~h})$ and hours later (15-48 $\mathrm{h}$ ) in mice cervices, as determined by proteomics and analyzed by ANOVA analysis. Over 150 proteins were found to be variably expressed, of which about 14 had a statistically significant change between 0 and $48 \mathrm{~h}$ postpartum. Red indicates higher protein expression and green indicates lower protein expression compared to baseline control $(n=3, P=0.05)$. 

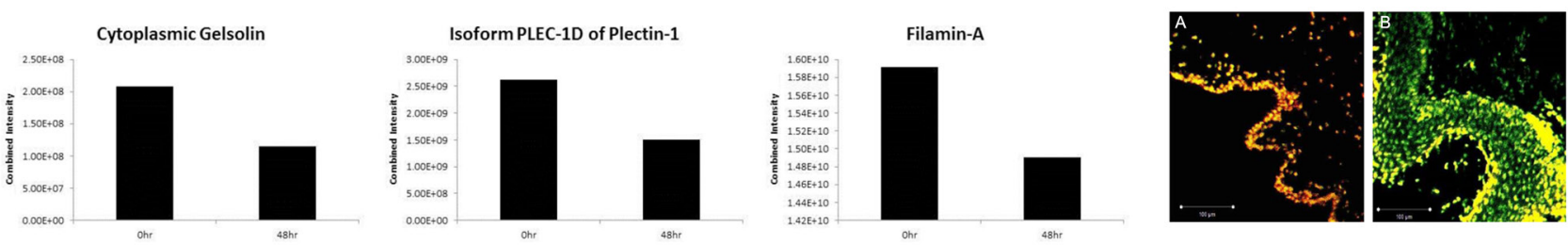

Figure 2

Protein expression profile of actin-binding proteins (ABPs) in postpartum (PP) mice cervix, as revealed by proteomics and verified by confocal immunofluorescence (filamin-A), i.e., gelsolin, plectin-1 and filamin-A showed elevated levels of all the three proteins at $0 \mathrm{~h}$ PP but decreased at $48 \mathrm{~h}$ PP in mice cervix. $n=3$. Filamin-A confocal immunofluorescence: $A=0 h ; B=48 \mathrm{~h}$. Red indicates higher protein expression, yellow indicates middle and green indicates lower protein expression compared to baseline control.

\section{Discussion}

Of the four phases of CR, postpartum repair is the least studied and to date, there is no comprehensive study that has focused exclusively on this fourth and final phase of CR. Here, using proteomics analysis, we identify over 150 proteins that were variably expressed, of which approximately 14 had a statistically significant change between 0 - and 48 -h postpartum. Through an extensive literature search, these 14 proteins were placed into one or more of the following categories: (a) intermediate filaments, (b) actin-binding proteins, (c) hypoxia-induced proteins and (d) proteins involved in immune modulation and/or wound healing.

Postpartum repair is characterized as a general inflammatory, wound-healing process (Timmons et al. 2010, Stanley et al. 2015). Specifically, there is a notable influx of tissue monocytes in the cervix shortly before birth as well as increased neutrophils postpartum (Timmons et al. 2009). These monocytes are then activated and differentiated into M1 and M2 macrophages (Timmons et al. 2009, 2010). However, the exact mechanisms that underlie the influx and activation of these immune cells during this process are unclear. It is possible that the local VEGF and HIF-1 $\alpha$ surge reported previously, and immediately prior to term (Mowa et al. 2004, Stanley et al. 2015), could be responsible for both the immune cell influx and the activation for the following reasons: (a) after the birth-induced mechanical trauma (injury), the hypoxia-induced VEGF secretion establishes a gradient that mirrors the hypoxic gradient (Alberts et al. 2008), and VEGF receptor-expressing immune cells, including macrophages and neutrophils, respond chemotactically to VEGF, thus migrating to the injury/hypoxic site (Galiano et al. 2004, Eming \& Krieg 2006, Bao et al. 2009); (b) under hypoxic conditions, HIF- $1 \alpha$ stimulates macrophages to secrete M1 pro-inflammatory cytokines (Acosta-Iborra et al. 2009) and (c) these recruited immune cells will secrete more VEGF and pro-inflammatory factors, as well as promote wound healing, angiogenesis and VEGF
Keratin II 18

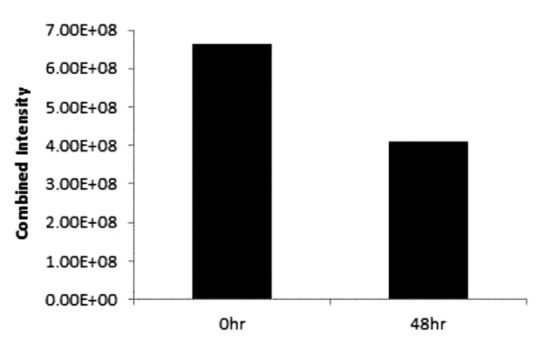

Vimentin

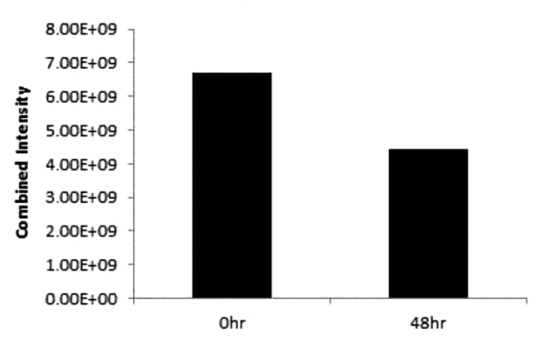

\section{Keratin I 8}

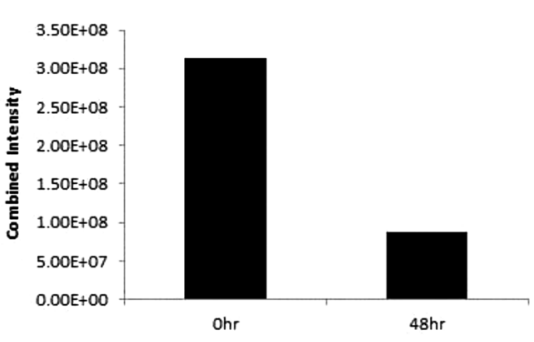

Desmin

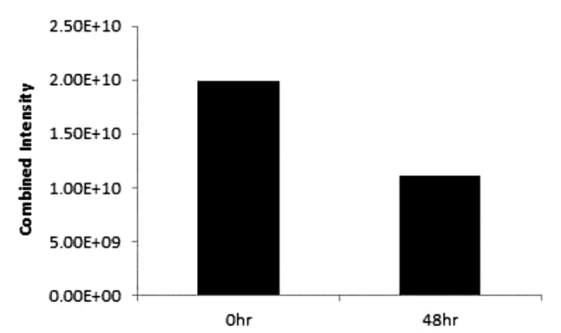

Figure 3

Protein expression of intermediate filaments proteins in postpartum (PP) mice cervix, as revealed by proteomics, i.e., levels of keratin II 18 , keratin I 8, desmin and vimentin were elevated at $0 \mathrm{~h}$ PP but decreased at $48 \mathrm{~h}$ PP in mice cervix. $n=3$. 
Glutamine gamma-

glutamyltransferase 2

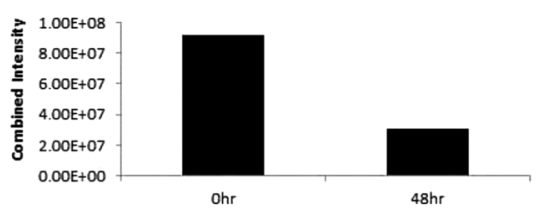

Lymphocyte antigen 6D

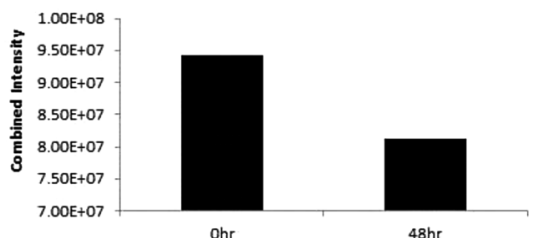

Cytoplasmic Gelsolin

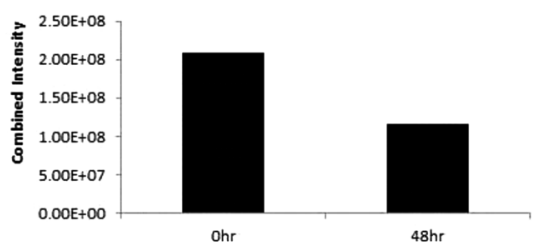

Phospholipase A2

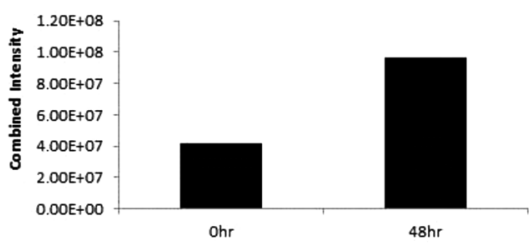

Annexin A1

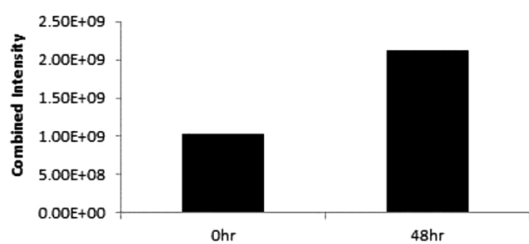

Macrophage migration inhibitory factor

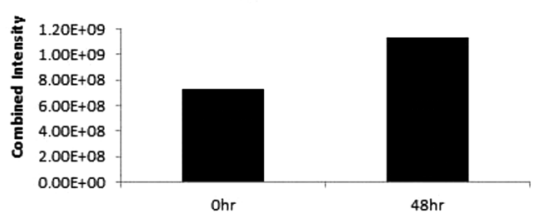

Figure 4

Protein expression analysis of proteins involved in immune modulation and wound healing in postpartum (PP) mice cervix, as revealed by proteomics. Levels of half of the six proteins (glutamine gamma-glutamyltransferase 2, lyphocyte antigen $6 \mathrm{D}$ and gelsolin) were high at $0 \mathrm{~h}$ but low at $48 \mathrm{~h} \mathrm{PP}$ and the expressions of the other half (phosphlipase A2, annexin A1 and macrophage migration inhibitory factor) were opposite of the first half. $n=3$. production in keratinocytes and fibroblasts (Galiano et al. 2004, Bao et al. 2009), cells that are known to play a critical role in wound healing. Further studies are required to confirm these speculations, as well as to shed more light on the alternate activation of the M2 phenotype.

The four intermediate filaments identified in the present study were keratins (type II 18 and type I 8), desmin and vimentin; overall, their expressions were elevated at $0 \mathrm{~h}$ PP but dropped at $48 \mathrm{~h}$ PP. Generally, intermediate filaments are among the three major cytoskeletal elements in eukaryotic cells, which are known to supply cellular strength and integrity by acting as intracellular scaffolds (Fuchs 1994). The two keratins (type II 18 and type I 8) are paired together (Singla et al. 2012), and are the major keratins found in epithelium (Tao et al. 2009). Desmin is associated with sarcomeres, nucleus and mitochondria of all muscle types (Paulin \& Li 2004), and is known to maintain cell integrity during contractions while helping force transmission and longitudinal load bearing (Paulin \& Li 2004, Bonakdar et al. 2012). Generally, vimentin is considered as the cytoskeletal element that maintains cell integrity (Goldman et al. 1996) and offers resilience to cells undergoing high mechanical strain (Haudenschild et al. 2011). However, while the adult phenotypes in mice lacking keratin are obvious and severe, e.g., severe skin fragility (Lloyd et al. 1995), it is not so with vimentin. For instance, and of relevance to the current study, vimentin deficiency impairs wound healing both in vitro and in vivo by diminishing the mobility of fibroblasts and their ability to induce collagen contraction, which is essential in wound healing (Eckes et al. 1998, 2000). Generally, wound healing in adulthood is normally characterized by an inflammatory response and by differentiation of the fibroblasts into a specialized contractile cell, the
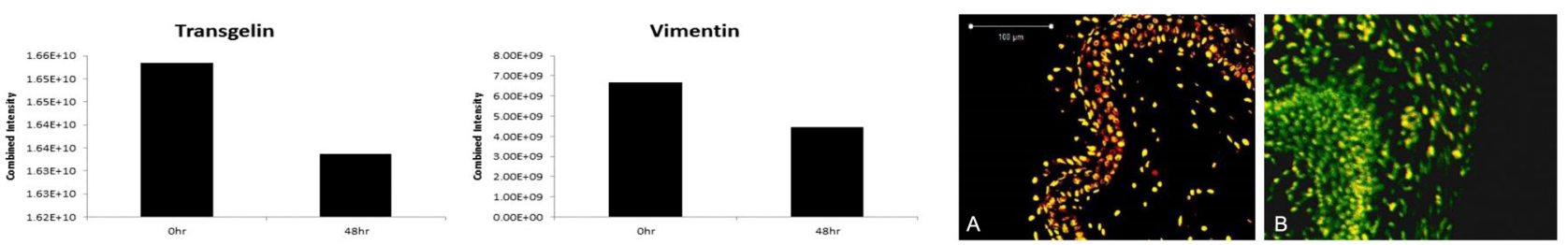

Figure 5

Protein expression profile of hypoxia-induced proteins in postpartum mice cervix, as revealed by proteomics and verified by confocal immunofluorescence (vimentin), i.e., transgelin and vimentin. Both proteins were elevated at $0 \mathrm{~h}$ PP and decreased at $48 \mathrm{~h}$ PP. Vimentin confocal immunofluorescence: $A=0 \mathrm{~h} ; \mathrm{B}=48 \mathrm{~h}$. Red indicates higher protein expression, yellow indicates middle and green indicates lower protein expression compared to baseline control. $N=3$. $A=0 h ; B=48 \mathrm{~h}$. 
Table 2 The key functional proteins significantly expressed in mice cervix the first $48 \mathrm{~h}$ postpartum.

\section{Protein functional group}

1. Intermediate filaments

3. Hypoxia-induced proteins

4. Immune modulation and/or wound healing

\begin{tabular}{l} 
Proteins changing in expression \\
- Keratins type II 18 \\
- Keratin type I 8 \\
- Desmin \\
- Vimentin \\
- Gelsolin \\
- Dilamin-A \\
- Transoform of plectin-1 \\
- Transgelin \\
- Vimentin \\
- Glutamine gamma-glutamyltranferase 2 \\
- Gelsolin \\
- Macrophage migration inhibitory factor \\
- Annexin A1 \\
- Phospholipase 2 \\
\hline
\end{tabular}

\section{Overall expression in postpartum}

- All are high at $0 \mathrm{~h}$ but drop by $48 \mathrm{~h}$ PP

- All are high at $0 \mathrm{~h}$ but drop by $48 \mathrm{~h}$ PP

- Both high at $0 \mathrm{~h}$ but drop by $48 \mathrm{~h}$ PP

- High at $0 \mathrm{~h}$ but drops by $48 \mathrm{~h}$ PP

- High at $0 \mathrm{~h}$ but drops by $48 \mathrm{~h}$ PP

- High at $15 \mathrm{~h}$ but low at $0 \mathrm{~h}$ and $48 \mathrm{~h}$ PP

- Low at $0 \mathrm{~h}$ but high by $48 \mathrm{~h}$ PP

- Low at $0 \mathrm{~h}$ but high by $48 \mathrm{~h}$ PP

- Low at $0 \mathrm{~h}$ but high by $48 \mathrm{~h}$ PP myofibroblast (Gabbiani et al. 1971, Martin 1997). It is feasible to speculate that the increased vimentin and desmin early in postpartum repair are necessary for the connective-tissue component of cervical repair, while keratin may play a similar role in the epithelial tissue (Eckes et al. 2000).

Any cellular process involving movement, such as proliferation, migration and morphological changes, requires continuous and rapid reorganization (assembly, disassembly) of actin filaments (dos Remedios et al. 2003). Such processes (actin filament assembly, disassembly and/or organization) are dependent on the presence of actin-binding proteins. Here, we detected four actinbinding proteins, whose expressions were elevated at $0 \mathrm{~h}$ postpartum, but decreased by $48 \mathrm{~h}$ postpartum. They include cytoplasmic gelsolin, filamin-A, the D isoform of plectin-1 and transgelin.

Gelsolin is a key regulator of actin filament disassembly, in a calcium-dependent manner, but also promotes actin polymerization and reorganization by severing then uncapping actin filaments (Sun et al. 1999). Although mice lacking gelsolin are viable and fertile, they have deficiencies in the organization of actin-based domains in osteoclasts and in the migratory capacity of neutrophils and macrophages during inflammation and wound healing (Witke et al. 1996). Also, gelsolin has been clinically associated with a variety of impairments in inflammation, cell invasion, immune cell recruitment and wound healing (Witke et al. 1996, Sun et al. 1999, Spinardi \& Witke 2007, Gonclaves et al. 2010).

Filamins are responsible for crosslinking actin filaments, anchoring transmembrane proteins and scaffolding proteins (Wang et al. 2012), whereas pectin is a very large protein found in nearly all mammalian cells that serve to link all three major components of the cytoskeleton to cellular junctions. By holding the cytoskeleton together, pectin helps maintain cell integrity and elasticity (Wiche 1998). Collectively, in the context of postpartum cervical repair, these actin-binding proteins could regulate a variety of locomotion-dependent processes, notably wound healing and immune responses. Further studies are needed to define their specific roles in the context of cervical repair.

Hypoxia is known to be involved in various physiological and/or pathological responses, but may also play a role in parturition. For instance, in the highaltitude mountain range of the Andes, expecting mothers induce childbirth at term by climbing to high elevations with a lower oxygen environment or hypoxia. Similarly, it is likely that hypoxia could account for the increased risk in preterm labor associated with smoking. Interestingly, the current proteomics approach revealed two hypoxiainduced proteins, transgelin and vimentin, that were highly expressed at $\mathrm{Oh}$ postpartum. Transgelin is an actincrosslinking protein known to be expressed in fibroblasts and smooth muscle (Kim et al. 2009, 2012), and is strongly expressed in both the uterus and the cervix. Recent studies by Kim et al. (2012) demonstrated that transgelin is upregulated by hypoxia, independent of HIF-1 $\alpha$, and that it (transgelin) also activates the insulin-like growth factor receptor 1 (IGFR1) signaling pathway under hypoxic stress. The IGFR1 pathway has recently been shown to promote cell survival under hypoxic stress (Gariboldi et al. 2010, Kim et al. 2012) by upregulating Hif1a gene transcription (Gariboldi et al. 2010) and stabilization of HIF-1 $\alpha$ protein (Piecewicz et al. 2012). This upregulation and stabilization of HIF-1 $\alpha$ by the IGFR1 axis have been shown to induce VEGF expression during embryonic vasculogenesis 
Table 3 Differentially expressed proteins.

\begin{tabular}{l} 
Primary protein name \\
\hline THIO_MOUSE \\
G3P_MOUSE \\
TBA4A_MOUSE \\
ALBU_MOUSE \\
SPR1A_MOUSE \\
ENOA_MOUSE \\
TAGL_MOUSE \\
Q3US43_MOUSE \\
TKT_MOUSE \\
GSTO1_MOUSE \\
ACTA_MOUSE \\
Q3UF30_MOUSE \\
GSTA4_MOUSE \\
GELS_MOUSE \\
Q9CX22_MOUSE \\
Q8BT24_MOUSE \\
FLNA_MOUSE \\
PLEC1_MOUSE \\
Q9Z1R9_MOUSE \\
FABP5_MOUSE \\
SAP_MOUSE \\
FETUA_MOUSE \\
QSOX1_MOUSE \\
Q3V2C6_MOUSE \\
A8DUV1_MOUSE \\
CLCA1_MOUSE \\
HBB2_MOUSE \\
PA21B_MOUSE \\
MIF_MOUSE \\
Q3UCF8_MOUSE \\
Q8K1G6_MOUSE \\
Q3TFD9_MOUSE \\
LUM_MOUSE \\
K2C8_MOUSE \\
1433S_MOUSE \\
Q8K0P6_MOUSE \\
B1AQ77_MOUSE \\
TGM2_MOUSE \\
PGRP1_MOUSE \\
Q91XG5_MOUSE \\
LY6D_MOUSE \\
\hline
\end{tabular}

Protein description
MCG2706
Glyceraldehyde-3-phosphate dehydrogenase
Tubulin alpha-4A chain
Putative uncharacterized protein
Putative uncharacterized protein
Enolase
Transgelin
Annexin A1
Transketolase
Glutathione S-transferase omega-1
Putative uncharacterized protein
Protein S100-A10
Glutathione S-transferase A4
Isoform cytoplasmic of gelsolin
Cofilin-1
Putative uncharacterized protein (fragment)
Filamin-A
Isoform PLEC-1D of plectin-1
Protease, serine, 1
Fatty acid-binding protein, epidermal
Sulfated glycoprotein 1
Alpha-2-HS-glycoprotein
Isoform 2 of sulfhydryl oxidase 1
Desmin
Alpha-globin
Calcium-activated chloride channel regulator 1
Hemoglobin subunit beta-2
Phospholipase A2
Macrophage migration inhibitory factor
Putative uncharacterized protein
Muc5b protein
Vimentin
Lumican
Keratin, type II cytoskeletal 8
Putative uncharacterized protein
Fcgbp protein (fragment)
Keratin, type I cytoskeletal 18
Protein-glutamine gamma-glutamyltransferase 2
Pglyrp1 protein
Protein S100-G
Lymphocyte antigen 6 D

15

Glyceraldehyde-3-phosphate dehydrogenase $\quad 48$

15

48

15

15

Transgelin

0

48

Glutathione S-transferase omega-1

15

15

erized protein

0,48

Glutathione S-transferase A4

48

Isoform cytoplasmic of gelsolin

15

0,15

15

15

Putative uncharacterized protein (fragment)

0

Isoform PLEC-1D of plectin-1

0,15

48

Fatty acid-binding protein, epidermal $\quad 15$

Sulfated glycoprotein 1

Alpha-2-HS-glycoprotein

48

15

Alpha-globin

Calcium-activated chloride channel regulator 1

0,15

15

15

0

Phospholipase A2

Macrophage migration inhibitory factor

48

48

0

48

0,15

Putative uncharacterized protein

Pglyrp1 protein $\quad 15$

Protein S100-G

Lymphocyte antigen 6D

Candidate protein markers based on label-free LC/MS/MS differential expression analysis.

(Piecewicz et al. 2012) and angiogenesis in malignant tumor cells under hypoxic stress (Gariboldi et al. 2010). Whether transgelin acts upstream of HIF- $1 \alpha$ and VEGF in postpartum cervical repair is for now speculative. The exact and diverse roles of trangelin during postpartum cervical repair require further inquiry. Like transgelin, vimentin has also been associated with hypoxia. For instance, it has been shown to redistribute among the endothelial cell into stable structures in response to hypoxia (Lui et al. 2010), is involved in general wound healing (Rogel et al. 2011) and is known to play a role in migrating cells, including fibroblasts, macrophages, endothelial cells and invasive cancer cells (Lui et al. 2010, Glaser-Gabay et al.

http://jme.endocrinology-journals.org https://doi.org/10.1530/JME-17-0179

(C) 2018 Society for Endocrinology Published by Bioscientifica Ltd.
Printed in Great Britain
2011, Helfand et al. 2011, Rogel et al. 2011). Future studies are needed to examine the roles of these hypoxia-induced proteins in the postpartum phase of CR.

Postpartum repair has been previously characterized as a pro-inflammatory and wound-healing process (Timmons \& Mahendroo 2007, Bauer et al. 2009, Gonzalez et al. 2009). Our current proteomics data of postpartum cervical tissue are consistent with the earlier studies. Here, we identified several proteins that have known immune-related functions, notably glutamine gammaglutamyltranferase 2, a transglutaminase, gelsolin, lymphocyte antigen 6D, macrophage MIF, annexin A1 and phospholipase 2. Transglutaminases are ubiquitous 
enzymes that are important in posttranslational modification of proteins (Sabatino et al. 2012), which participate in coagulation and wound-healing responses (Upchurch et al. 1991, Aeschlimann \& Paulsson 1994). Glutamine gamma-glutamyltransferase 2, often referred to as transglutaminase 2, is an enzyme that is important in the remodeling of ECM (Sabatino et al. 2012) and was found to be highly expressed at $0 \mathrm{~h}$ postpartum followed by a decrease in expression at $48 \mathrm{~h}$ postpartum. It is feasible that it may regulate cervical hemorrhage during parturition in addition to the extensive ECM remodeling that takes place after parturition (Timmons \& Mahendroo 2007, 2010, Gonzalez et al. 2009). The role of gelsolin in inflammation, immune responses and wound healing has been discussed previously (Witke et al. 1996, Sun et al. 1999, Spinardi \& Witke 2007, Goncalves et al. 2010) and is consistent with previous studies that report increases in various immune cell populations just after birth (Timmons et al. 2009).
Another protein of interest detected at high levels at $0 \mathrm{~h}$ postpartum compared to $48 \mathrm{~h}$ postpartum was lymphocyte antigen 6D (LY6D). LY6D is a marker found on mature B cells and specific populations of dendritic cells (Inlay et al. 2009) and is implicated in DNA damage control (Kurosawa et al. 2012), implying an increase in either dendritic or B cells postpartum. However, such cell types have not yet been reported postpartum.

Another protein noted in the present study involved in the immune response is macrophage MIF, and is one of the earliest cytokines to be discovered in the 1960s. MIF is a pro-inflammatory cytokine involved in the innate immune response (Calandra 2003, Roger et al. 2013), and was first characterized to play a large role in delayed hypersensitivity reactions (Bloom \& Bennett 1970). These reactions involve interactions between T-cells and macrophages rather than antibodies, and MIF has broad cytokine actions that modulate T-cell responses (Choi et al. 2012), as well as $\mathrm{T}$ cell-macrophage interactions

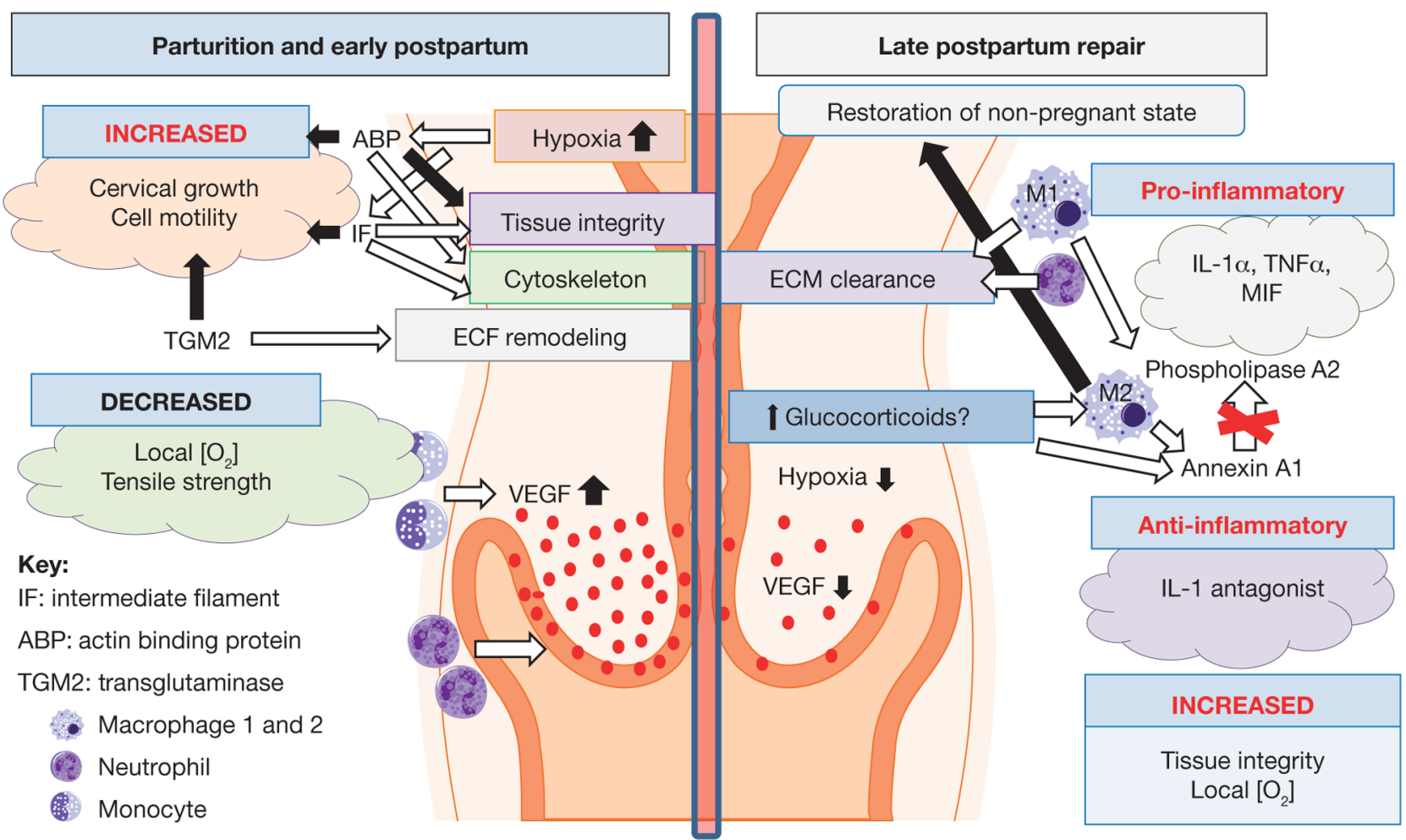

\section{Figure 6}

Proposed working model of postpartum repair in the mouse. Cervical postpartum repair involves a combination of pro- and anti-inflammatory actions. At parturition and immediately after postpartum, the cervix is large and pliable without losing cell integrity; this is accomplished by ECM remodeling by transglutaminase 2 (TGM2) and cytoskeletal reorganization by both intermediate filaments (IF) and actin-binding proteins (ABPs). Tissue growth increases distances to nearby blood vessels, creating local hypoxia, which regulates certain IF and ABP while inducing VEGF secretion. Monocytes (M), as well as neutrophils $(\mathrm{N})$, respond chemotactically to VEGF and migrate to the site of hypoxia/injury. Postpartum repair is a balance of pro- and anti-inflammatory processes, and monocytes are activated to M1 or M2 macrophage phenotypes. M1 and N will protect the cervix, secrete pro-inflammatory cytokines and aid in the clearance of damaged ECM molecules. M2 promotes tissue repair and keeps inflammation in check, e.g., annexin A1 inhibits the pro-inflammatory enzyme phospholipase A2. Glucocorticoids may induce the M2 phenotype and annexin A1. Tissue size is decreased, $\mathrm{O}_{2}$ is restored and VEGF production is reduced. 
(Nishihira 2000). MIF is also known to be secreted by the pituitary (Nishihira 2000). With MIF being elevated at $48 \mathrm{~h}$ postpartum, we speculate that a delayed hypersensitivity reaction could be taking place in the postpartum cervix, providing further support for a protective role of MIF from potential microbial invasion likely to occur immediately after birth.

One of the key changes occurring during the postpartum phase of $\mathrm{CR}$ is the conversion of monocytes to activated macrophages (M1, classical pro-inflammatory, and M2, alternative anti-inflammatory) (Timmons et al. 2009, 2010). The pro-inflammatory M1 and neutrophils would serve to aid with the clearance of ECM molecules (Timmons et al. 2010) while protecting the birth canal from foreign invaders (Gonzalez et al. 2009, Timmons et al. 2009), whereas the anti-inflammatory effects could serve to keep the pro-inflammatory effects in check (Timmons et al. 2010), which if left unregulated could potentially cause damage to the birth canal, putting subsequent pregnancies in jeopardy. In this study, we have identified a few potential players in the balancing act of pro- and anti-inflammatory levels and effects.

Finally, two proteins associated with immune responses, annexin A1 and phospholipase A2, were elevated at $48 \mathrm{~h}$ postpartum compared to $0 \mathrm{~h}$ postpartum. These two proteins have contradictory effects. Phospholipase A2 is a calcium-dependent enzyme that hydrolyzes glyercophospholipids into free intracellular arachidonic acid, the precursor for eicosanoids (Dennis 1994), including prostaglandins and leukotrienes, and as such is involved in inflammation and host defense. In contrast, annexin A1, also known as lipocortin, is a calcium-dependent phospholipid-binding protein that will inhibit phospholipase A2 as well as mediate VEGFinduced angiogenesis (Pin et al. 2012). Glucocorticoids stimulate production of annexin $\mathrm{A} 1$ and activation of M2 anti-inflammatory macrophages (Mantovani et al. 2006). It is interesting that both of these are elevated simultaneously, i.e., at $48 \mathrm{~h}$ postpartum even though they have apparent contradictory effects. This pattern, however, supports earlier suggestions that there is a check and balance in play between pro- and antiinflammatory factors in the postpartum repair of the cervix.

In summary, our data support the current thinking in the field of $\mathrm{CR}$ that postpartum repair involves a combination of pro- and anti-inflammatory actions. From all the data gathered in the present study, along with what has already been characterized previously with regard to postpartum cervical repair, we propose a working model
(Fig. 6). Future studies will assess the suitability of some of the key proteins identified in this study as potential markers for determining the phase of postpartum cervical repair.

\section{Declaration of interest}

The authors declare that there are no conflicts of interest that could be perceived as prejudicing the impartiality of the research reported.

\section{Funding}

Funding for the present study was provided by the College of Arts and Sciences, Graduate School and Office of Student Research at Appalachian State University, Boone, NC, USA.

\section{Author contribution statement}

Robert Lee Stanley performed most of the work. Takako Ohashi and Jacob Gordon assisted in the Western blot and confocal immunofluorescence. Analysis and interpretation of data and write up of paper were done by Robert Lee Stanley with assistance from Chishimba Nathan Mowa. Chishimba Nathan Mowa is the principal investigator.

\section{Acknowledgements}

The authors thank the funders, the thesis committee members (Sue Bauldry, Guichuan Hou, Sue Edwards) and all the lab members of the Mowa lab, notably Catherine Burton, Siobhan Donnelley, Ben Coe, Jordan Estes, Molly Fike and BaoTran Nguyen.

\section{References}

Acosta-Iborra B, Elorza A, Olazabal IM, Martin-Cofreces NB, Martin-Puig S, Miro M, Calzada MJ, Aragones J, Sanchez-Madrid F \& Landazuri MO 2009 Macrophage oxygen sensing modulates antigen presentation and phagocytic functions involving IFN- $\gamma$ production through the HIF- $1 \alpha$ transcription factor. Journal of Immunology 182 3155-3164. (https://doi.org/10.4049/jimmunol.0801710)

Aeschlimann D \& Paulsson M 1994 Transglutaminases: protein crosslinking enzymes in tissues and body fluids. Thrombosis and Hemostasis 71 402-415.

Alberts B, Johnson A, Lewis J, Raff M, Roberts K \& Walter P 2008 Molecular Biology of the Cell, pp 1417-1482. New York, NY, USA: Garland Science.

Bao P, Kodra A, Tomic-Canic M, Golinko MS, Ehrlich HP \& Brem H 2009 The role of vascular endothelial growth factor in wound healing. Journal of Surgical Research 15 347-358. (https://doi. org/10.1016/j.jss.2008.04.023)

Bauer M, Mazza E, Jabareen M, Sultan L, Bajka M, Lang U, Zimmermann R \& Holzapfel GA 2009 Assessment of the in vivo biomechanical properties of the human uterine cervix in pregnancy using the aspiration test a feasibility study. European Journal of Obstetrics and Gynecology $144 S$ S77-S81. (https://doi.org/10.1016/j. ejogrb.2009.02.025)

Bloom BR \& Bennett B 1970 Relation of the migration inhibitory factor (MIF) to delayed-type hypersensitivity reactions. Annals of New York Academy of Sciences 169 258-265. (https://doi. org/10.1111/j.1749-6632.1970.tb55994.x) 
Bonakdar N, Luczak J, Lautscham L, Czonstke M, Koch TM, Mainka A, Jungbauer T, Goldmann WH, Schroder R \& Fabry B 2012 Biomechanical characterization of desminopathy in primary human myoblasts. Biochemical and Biophysical Research Communications 419 703-707. (https://doi.org/10.1016/j.bbrc.2012.02.083)

Calandra T 2003 Macrophage migration inhibitory factor and host innate immune responses to microbes. Scandinavian Journal of Infectious Diseases 35 573-576. (https://doi. org/10.1080/00365540310016277)

Choi S, Kim HR, Leng L, Kang I, Jorgensen WL, Cho CS, Bucala R \& Kim WU 2012 Role of macrophage inhibitory factor in the regulatory $\mathrm{T}$ cell response of tumor-bearing mice. Journal of Immunology 189 3905-3913. (https://doi.org/10.4049/ jimmunol.1102152)

Dennis EA 1994 Diversity of group types, regulation, and function of phospholipase A2. Journal of Biological Chemistry 269 13057-13060.

dos Remedios CG, Chhabra D, Kekic M, Dedova IV, Tsubakihara M, Berry DA \& Nosworthy NJ 2003 Actin binding proteins: regulation of cytoskeletal filaments. Physiological Reviews 83 433-473. (https:// doi.org/10.1152/physrev.00026.2002)

Eckes B, Dogic D, Colucci-Guyon E, Wang N, Maniotis A, Ingber D, Merckling A, Langa F, Aumailley M, Delouvee A, et al. 1998 Impaired mechanical stability, migration and contractile capacity in vimentindeficient fibroblasts. Journal of Cell Sciences 111 1897-1907.

Eckes B, Colucci-Guyon E, Smola H, Nodder S, Babinet C, Krieg T \& Martin P 2000 Impaired wound healing in embryonic and adult mice lacking vimentin. Journal of Cell Sciences 113 2455-2462.

Eming SA \& Krieg T 2006 Molecular mechanisms of VEGF-A action during tissue repair. Journal of Investigative Dermatology 11 79-86. (https://doi.org/10.1038/sj.jidsymp.5650016)

Fuchs E 1994 Intermediate filaments and disease: mutations that cripple cell strength. Journal of Cell Biology 125 511-516. (https://doi. org/10.1083/jcb.125.3.511)

Gabbiani G, Ryan GB \& Majne G 1971 Presence of modified fibroblasts in granulation tissue and their possible role in wound contraction. Experientia 27 549-550. (https://doi.org/10.1007/BF02147594)

Galiano RD, Tepper OM, Pelo CR, Bhatt KA, Callaghan M, Bastidas N, Bunting S, Steinmetz HG \& Gurtner GC 2004 Topical vascular endothelial growth factor accelerates diabetic wound healing through increased angiogenesis and by mobilizing and recruiting bone marrow-derived cells. American Journal of Pathology 164 1935-1947. (https://doi.org/10.1016/S0002-9440(10)63754-6)

Gariboldi MB, Ravizza R \& Monti E 2010 The IGFR1 inhibitor NVPAEW541 disrupts a pro-survival and pro-angiogenic IGF-STAT3-HIF1 pathway in human glioblastoma cells. Biochemical Pharmacology 80 455-462. (https://doi.org/10.1016/j.bcp.2010.05.011)

Glaser-Gabay L, Raiter A, Battler A \& Hardy B 2011 Endothelial cell surface vimentin binding peptide induces angiogenesis under hypoxic/ischemic conditions. Microvascular Research 82 221-226. (https://doi.org/10.1016/j.mvr.2011.07.006)

Goldman RD, Khuon S, Chou YH, Opal P \& Steinert PM 1996 The function of intermediate filaments in cell shape and cytoskeletal integrity. Journal of Cell Biology 134 971-983. (https://doi. org/10.1083/jcb.134.4.971)

Goncalves AF, Dias NG, Moransard M, Correia R, Pereira JA, Witke W, Suter U \& Relvas JB 2010 Gelsolin is required for macrophage recruitment during remyelination of the peripheral nervous system. Glia 58 706-715.

Gonzalez JM, Xu H, Chai J, Ofori E \& Elovitz MA 2009 Preterm and term cervical ripening in CD1 mice (Mus musculus): similar or divergent molecular mechanisms? Biology of Reproduction $\mathbf{8 1}$ 1226-1232. (https://doi.org/10.1095/biolreprod.108.075309)

Haudenschild DR, Chen J, Pang N, Steklov N, Grogan SP, Lotz MK \& D'Lima DD 2011 Vimentin contributes to changes in chondrocyte stiffness in osteoarthritis. Journal of Orthopaedic Research 29 20-25. (https://doi.org/10.1002/jor.21198)
Helfand BT, Mendez MG, Murthy SN, Shumaker DK, Grin B, Mahammad S, Aebi U, Wedig T, Wu YI, Hahn KM, et al. 2011 Vimentin organization modulates the formation of lamellipodia. Molecular Biology of the Cell 22 1274-1289. (https://doi.org/10.1091/ mbc.E10-08-0699)

Inlay MA, Bhattacharya D, Sahoo D, Serwold T, Seita J, Karsunky H, Plevritis SK, Dill DL \& Weissman IL 2009 Ly6d marks the earliest stage of B-cell specification and identifies the branchpoint between B-cell and T-cell development. Gene and Development 23 2376-2381. (https://doi.org/10.1101/gad.1836009)

Kim TR, Moon JH, Lee HM, Cho EW, Paik SG \& Kim IG 2009 SM22alpha inhibits cell proliferation and protects against anticancer drugs and gamma-radiation in HepG2 cells: involvement of metallothioneins. FEBS Letters 583 3356-3362. (https://doi. org/10.1016/j.febslet.2009.09.040)

Kim TR, Cho EW, Paik SG \& Kim IG 2012 Hypoxia-induced SM22 $\alpha$ in A549 cells activates the IGF1R/PI3K/Akt pathway, conferring cellular resistance against chemo-and radiation therapy. FEBS Letters $\mathbf{5 8 6}$ 303-309. (https://doi.org/10.1016/j.febslet.2011.12.036)

Kurosawa M, Jeyasekharan AD, Surmann EM, Hashimoto N, Venkatraman V, Kurosawa G, Furukawa K, Venkitaraman AR \& Kurosawa Y 2012 Expression of LY6D is induced at the surface of MCF10A cells by X-ray irradiation. FEBS Journal 279 4479-4491. (https://doi.org/10.1111/febs.12034)

Lloyd C, Yu QC, Cheng J, Turksen K, Degenstein L, Hutton E \& Fuchs E 1995 The basal keratin network of stratified squamous epithelia: defining K15 function in the absence of K14. Journal of Cellular Biology 129 1329-1344. (https://doi.org/10.1083/ jcb.129.5.1329)

Lui T, Guevara OE, Warburton RR, Hill NS, Gaestel M \& Kayyali US 2010 Regulation of vimentin intermediate filaments in endothelial cells by hypoxia. American Journal of Physiology: Cell Physiology 299 C363-C373. (https://doi.org/10.1152/ajpcell.00057.2010)

Mahendroo M 2012 Cervical remodeling in term and preterm birth: insights from an animal model. Reproduction 143 429-438. (https:// doi.org/10.1530/REP-11-0466)

Mantovani A, Sica A \& Locati M 2006 New vistas on macrophage differentiation and activation. European Journal of Immunology $\mathbf{3 7}$ 14-16. (https://doi.org/10.1002/eji.200636910)

Martin P 1997 Wound healing-aiming for perfect skin regeneration. Science 276 75-81. (https://doi.org/10.1126/science.276.5309.75)

Mowa CN, Jesmin S, Sakuma I, Usip S, Togashi H, Yoshioka M, Hattori Y \& Papka R 2004 Characterization of vascular endothelial growth factor (VEGF) in the uterine cervix over pregnancy: effects of denervation and implications for cervical ripening. Journal of Histochemistry and Cytochemistry 52 1665-1674. (https://doi. org/10.1369/jhc.4A6455.2004)

Nishihira J 2000 Macrophage migration inhibitory factor (MIF): it's essential role in the immune system and cell growth. Journal of Interferon and Cytokine Research 20 751-762. (https://doi. org/10.1089/10799900050151012)

Paulin D \& Li Z 2004 Desmin: a major intermediate filament protein essential for structural integrity and function of muscle. Experimental Cell Research 301 1-7. (https://doi.org/10.1016/j.yexcr.2004.08.004)

Piecewicz SM, Pandey A, Roy B, Xiang SH, Zetter BR \& Sengupta S 2012 Insulin-like growth factors promote vasculogenesis in embryonic stem cells. PLoS ONE 7 e32191. (https://doi.org/10.1371/journal. pone.0032191)

Pin AL, Houle F, Fournier P, Guillonneau M, Paquet ER, Simard MJ, Royal I \& Huot J 2012 Annexin A1-mediated endothelial cell migration and angiogenesis are regulated by vascular endothelial growth factor (VEGF)-induced inhibition of miR-196a expression. Journal of Biological Chemistry 287 30541-30551. (https://doi. org/10.1074/jbc.M112.393561)

Read CP, Word RA, Ruschenisky MA, Timmons BC \& Mahendroo M 2007 Cervical remodeling during pregnancy and parturition: 
molecular characterization of the softening phase in mice. Reproduction 134 327-340. (https://doi.org/10.1530/REP-07-0032)

Rogel MR, Soni PN, Troken JR, Sitikov A, Trejo HE \& Ridge KM 2011 Vimentin is sufficient and required for wound repair and remodeling in alveolar epithelial cells. FASEB Journal 25 3873-3883. (https://doi. org/10.1096/fj.10-170795)

Roger T, Delaloye J, Chanson AL, Giddey M, Le Roy D \& Calandra T 2013 Macrophage migration inhibitory factor deficiency is associated with impaired killing of gram-negative bacteria by macrophages and increased susceptibility to Klebsiella pneumonia sepsis. Journal of Infectious Diseases 207 331-339. (https://doi.org/10.1093/infdis/jis673)

Sabatino AD, Vanoli A, Giuffrida P, Luinetti O, Solcia E \& Corazza GR 2012 The function of tissue transglutaminase in celiac disease. Autoimmune Review 11 746-753. (https://doi.org/10.1016/j. autrev.2012.01.007)

Singla A, Moons DS, Snider NT, Wagenmaker ER, Jayasundera VB \& Omary MB 2012 Oxidative stress, Nrf2 and keratin up-regulation associate with Mallory-Denk formation in mouse erythropoietic protoporphyra. Hepatology 56 322-331. (https://doi.org/10.1002/ hep.25664)

Spinardi L \& Witke W 2007 Gelsolin and diseases. Subcellular Biochemistry 45 55-69.

Stanley R, Ohashi T \& Mowa C 2015 Postpartum cervical repair in mice: a morphological characterization and potential role for angiogenic factors. Cell and Tissue Research 362 253-263. (https://doi. org/10.1007/s00441-015-2184-x)

Sun HQ, Yamamoto M, Mejillano M \& Yin HL 1999 Gelsolin, a multifunctional actin regulatory protein. Journal of Biological Chemistry 274 33179-33182. (https://doi.org/10.1074/jbc.274.47.33179)

Tao GZ, Looi KS, Toivola DM, Strnad P, Zhou Q, Liao J, Wei Y, Habtezion A \& Omary MB 2009 Keratins modulate the shape and function of hepatocyte mitochondria: a mechanism for protection from apoptosis. Journal of Cell Sciences 122 3851-3855. (https://doi. org/10.1242/jcs.051862)

Timmons BC \& Mahendroo M 2007 Process regulating cervical ripening differ from cervical dilation and postpartum repair: insights from gene expression studies. Reproductive Sciences 14 53-62. (https://doi. org/10.1177/1933719107309587)

Timmons BC, Fairhurst AM \& Mahendroo M 2009 Temporal changes in myeloid cells in the cervix during pregnancy and parturition. Journal of Immunology 182 2700-2707. (https://doi.org/10.4049/ jimmunol.0803138)

Timmons BC, Akins M \& Mahendroo M 2010 Cervical remodeling during pregnancy and parturition. Trends in Endocrinology and Metabolism 21 353-361. (https://doi.org/10.1016/j.tem.2010.01.011)

Upchurch HF, Conway E, Patterson MK Jr \& Maxwell MD 1991 Localization of cellular transglutaminases on the extracellular matrix after wounding: characteristics of the matrix bound enzyme. Journal of Cell Physiology 149 375-382. (https://doi.org/10.1002/ jсp.1041490304)

Wang Q, Dai XQ, Li Q, Wang Z, Cantero Mdel R, Li S, Shen J, Tu JC, Cantiello H \& Chen XZ 2012 Structural interaction and functional regulation of polysystin-2 by filamin. PLoS ONE 7 e40448. (https:// doi.org/10.1371/journal.pone.0040448)

Wiche G 1998 Role of plectin in cytoskeleton organization and dynamics. Journal of Cell Sciences 111 2477-2486.

Witke W, Sharpe AH, Hartwig JH, Azuma T, Stossel TP \& Kwiatkowski DJ 1996 Hemostatic, inflammatory, and fibroblast responses are blunted in mice lacking gelsolin. Cell 81 41-51. (https://doi. org/10.1016/0092-8674(95)90369-0)

Word RA, Li XH, Hnat M \& Carrick K 2007 Dynamics of cervical remodeling during pregnancy and parturition: mechanisms and current concepts. Seminars in Reproductive Medicine 25 69-79. (https://doi.org/10.1055/s-2006-956777)

Received in final form 9 November 2017 Accepted 15 November 2017 (c) 2018 Society for Endocrinology Published by Bioscientifica Ltd. Printed in Great Britain 